\title{
What, When and Who: \\ Manager Involvement in Predicting Employee Resistance to Acquisition Integration
}

\begin{abstract}
Applying sensemaking research to acquisition integration, we outline factors that influence employee resistance to acquisitions. While integration is widely viewed as important to acquisition outcomes, there is limited systematic study of how employees react to the integration process. Using survey data from Chinese acquirers and applying partial least squares structural equation modelling, we examine what changes with human and task integration with the speed of when changes are made to explore relationships with employee resistance. Consistent with a temporal perspective of acquisition processes and sensemaking we find slower task integration may mitigate employee resistance to acquisition integration. However, employee resistance to the speed that changes are made likely varies for who is involved, suggesting different roles for top and middle managers. Specifically, middle management involvement with slow human integration and top management involvement with fast task integration reduces employee resistance following an acquisition.
\end{abstract}




\section{Introduction}

During acquisitions, research recognizes that Human Resource Management (HRM) has a facilitating role for successful knowledge transfer associated and an absorptive capacity for target firms and employees that improves organizational performance (Katou, Budhwar \& Patel, 2014; Liu \& Meyer, 2018; Zhou, Fey, \& Yildiz, 2018). Associated research recognizes that acquisitions provide an interesting context to investigate employee reactions (Edwards \& Edwards, 2013; 2015). For example, changes associated with acquisition integration increase the risk of employee resistance that represents a primary reason for acquisition failure (Drori, Wrzesniewski \& Ellis, 2011; Larsson \& Finkelstein, 1999; Melkonian, Monin \& Noorderhaven, 2011). Increased recognition that integration is difficult and often harder to implement than expected (Colman \& Rouzies, 2018; Rouzies, Colman \& Angwin, 2018; Vaara, 2003) has led to research on acquisition integration and an examination of what influences its outcomes (Gill, 2012; Graebner, Heimeriks, Huy \& Vaara, 2017; Pickering, 2017; Sarala, Vaara, \& Junni, 2017; Teerikangas, Véry \& Pisano, 2011). While some level of integration of an acquired firm is necessary (Shrivastava, 1986; Vermeulen, 2005), integration is disruptive to employees of combining firms and it contributes to: 1) fear of job loss (Schweiger \& Denisi, 1991), 2) perceptions of unfair treatment and negative career effects (Fried et al., 1996), 3) anxiety over changed social relationships (Astrachan, 1995), and 4) increased uncertainty and stress (Cartwright \& Cooper, 1993; Marmenout, 2010). Although disruptions to employees from acquisition integration can contribute to employee resistance (Larsson \& Finkelstein, 1999), a better understanding of what influences employee resistance is still needed (Meglio, King \& Risberg, 2015; Ellis, Weber, Raveh \& Tarba, 2012).

By examining key decisions during acquisition integration that influences employee perceptions and acquisition outcomes (e.g., Jemison \& Sitkin, 1986; Shi \& Prescott, 2011, 2012), 
we argue that considering what changes with when it changes and who manages integration efforts can improve our understanding of acquisition outcomes. Building on insights that employee resistance is associated with acquisition failure (e.g. Larsson \& Finkelstein, 1999), we examine the pace and level of managerial intervention in predicting employee resistance to human and task integration. Our aim is to develop and test a framework that predicts employee resistance to an acquisition.

Building on the theoretical foundation of sensemaking and sensegiving (Maitlis, \& Christianson, 2014; Maitlis \& Sonenshein, 2010; Weick, 1995), we examine differential roles by top and middle managers during acquisition integration. Although top managers are assumed to initiate and lead integration, the role of middle managers in implementing change following an acquisition remains largely unexplored (Meglio \& Risberg, 2010; Meyer, 2006). While top management begins integration planning (Cullinan, Le Roux \& Weddigen, 2004), middle managers confront problems of implementing changes they did not plan and dealing with employee fears of those changes (Balogun \& Johnson, 2004).

Addressing these topics offers multiple contributions. First, our study supports acquisition research on human and task integration to develop how what changes during acquisition integration influences employee resistance (e.g., Larsson \& Finkelstein, 1999; Seo \& Hill, 2005). Second, we contribute to a process view (Jemison \& Sitkin, 1986), specifically responding to insights that understanding employee responses to an acquisition requires a greater focus on integration speed (Stahl et al., 2013), or when changes are made (Birkinshaw, Bresman \& Hakanson, 2000). Third, we increase clarity about agency in acquisitions by examining who is involved in setting and implementing human and task integration. By distinguishing the impact of managers at different hierarchical levels on employee resistance, we develop differences in top and middle managers sensegiving and provide insights into the role of managers during 
integration. In so doing, we examine unique primary data using acquirers from an emerging economy, more precisely China, complementing a bias in management research towards Western economies (cf. Meglio \& Risberg, 2011). However, this may also limit generalizability.

\section{Theory and Hypothesis Development}

Following an acquisition, employees expect change (Risberg, 1997), but managing the uncertainty typically associated with substantial organizational change, such as an acquisition, requires manager sensemaking and sensegiving (Clark, Gioia, Ketchen, \& Thomas, 2010; Gioia \& Chittipeddi, 1991). Sensemaking involves meaning construction and reconstruction in developing frameworks to understand intended changes (Gioia \& Chittipeddi, 1991; Stensaker, Falkenberg \& Gronhaug, 2008). Meanwhile, sensegiving involves the process of attempting to influence the sensemaking and meaning construction of others toward desired changes (Gioia \& Chittipeddi, 1991; Stensaker et al., 2008). However, most research assumes that managers direct change without examining the processes of how change is implemented (Sonenshein, 2010; Steigenberger, 2017), or recognizing that managers are also involved in sensemaking (Vaara. 2003; Monin, Noorderhaven, Vaara \& Kroon, 2013). For both integration planning and sensegiving, either too little or too much detail is possible (e.g., Eisenhardt, Furr \& Bingham, 2010; Henneberg, Naude \& Mouzas, 2010) with the implication that what changes, the speed it changes (when), and managerial roles, or who is involved at different levels of an organization likely influence employee resistance to change. As a result, the initial relationships in our framework rest on research on acquisition integration and associated changes that lead to the need for sensemaking, see Figure 1.

Insert Figure 1 about here 


\section{What Changes, or Type of Integration}

Acquisition integration essentially involves organizational change (King, Bauer \& Schriber, 2018), and research on change suggests a consideration of 'high impact' elements of change may be necessary to transform organizations (Amis, Slack \& Hinings, 2004). We combine the element of pace (speed) highlighted by Amis and colleagues (2004) with recognized dimensions of acquisition integration. Specifically, integration involves human and task integration that are distinct, but inter-related concepts that drive acquisition success (Bauer, King \& Matzler, 2016; Birkinshaw et al., 2000; Bauer, Schriber, Degischer \& King, 2018). Human integration addresses human resource management (i.e., pay and benefits) and organizational culture (Cording, Christmann \& King., 2008), and it focuses on creating positive attitudes and a shared identity (Meglio et al., 2015; Schweiger, Ivancevich \& Power, 1987). For example, Vaara (2003) finds that overlooking people issues during integration often proves detrimental. Meanwhile, the task integration focuses on operational efficiencies from combining organizational functions to improve efficiency and organizational coordination (Bauer et al., 2016; Cording et al., 2008; Meglio et al., 2015), and on transferring and sharing resources and capabilities (Birkinshaw et al., 2000).

Human Integration. Acquisitions disrupt employees and create uncertainty (Rafferty \& Restubog, 2010), as employees are confronted by possible job losses, increased workload, and changes in reporting relationships (Ullrich \& van Dick, 2007). Associated changes in employee identity contribute to employee resistance following an acquisition (Cho, Lee \& Kim, 2014; Ullrich, Wieseke \& van Dick, 2005). However, a heightened awareness of human aspects of acquisitions can reduce conflict and resistance following an acquisition (Ellis, Weber, Raveh \& Tarba, 2012; Seo \& Hill, 2005) by establishing mutual understanding and trust (Birkinshaw et al., 2000; Stahl, Larsson, Kremershof \& Sitkin, 2011). Trust is important to acquisition success and 
building it requires sensemaking of intentions (Searle \& Ball, 2004). As a result, demonstrating a firm's commitment to employees with human integration (Bauer et al., 2018) can build organizational cohesion (Rouzies et al., 2018) and reduce employee resistance. For example, human integration may decrease employee career uncertainty and lessen fear of job loss. Conversely, overlooking human integration concerns can be detrimental to acquisition integration (Vaara, 2003). Therefore, we predict:

Hypothesis 1a: Human integration decreases employee resistance following an acquisition.

Task integration. Task integration creates value from updating employee work processes (Colman \& Lunnan, 2011). However, coordination between combining firms on work processes disrupts prior employee routines (Bauer et al., 2016). As a result, updating work processes inevitably lowers task performance and contributes to employee resistance (Bauer et al., 2016; Cooke \& Huang, 2011). For example, change in developed processes impacts the ability of teams to coordinate on interdependent tasks, as efforts become either fragmented or duplicated (Summers, Humphrey \& Ferris, 2012). As a result, task integration addresses coordination in updated processes, as well as discontinuation of prior tasks (Rouzies et al., 2018). Still, acquisitions often struggle because employees experience discontinuity in job tasks (Paruchuri, Nerkar \& Hambrick, 2006; Ullrich et al., 2005), and this may contribute to employee resistance. Therefore, we predict:

Hypothesis $1 b$ : Task integration increases employee resistance following an acquisition.

\section{When it changes, or Duration of Integration}

An important decision for both human and task integration involves the speed under which changes are made (Bauer, King \& Matzler, 2016; Meglio et al., 2017). While managers in general prefer greater integration speed to accelerate improvements (e.g., Schlaepfer et al., 2008), 
employees might react either positively to reinforce improvements or negatively with resistance that unravels initial positive effects of human and task integration. This leads us to anticipate that human and task integration duration mediates the influence of human and task integration on employee resistance. Additionally, the impact of human and task integration is not free of constraints and depends on other contingencies, such as fit (Homburg \& Bucerius, 2006), decision-making preferences (Uzelac et al., 2016), and institutions (Bauer et al., 2018). Therefore, we also argue later that the influence of integration duration is likely moderated by whether top management or middle management is responsible for the different dimensions of acquisition integration and associated sensegiving.

Human integration speed. How quickly managers attempt to establish a positive environment between combining firms during integration is an important consideration. Fast human integration can minimize disruption and prevent employee resistance (Angwin, 2004, Bauer et al., 2016). Moving quickly with human integration can also take advantage of initial optimism from an acquisition (Buono \& Bowdich, 2003), as employees anticipate changes following an acquisition (Risberg, 1997). Further, an early focus on collaboration can minimize conflicts and employee uncertainty (Jansen, Tempelaar, Van den Bosch \& Volberta, 2009; Ullrich \& can Dick, 2007; Vaara, 2003). As a result, moving quickly with human integration can create positive momentum (Gates \& Very, 2003), and speed can help to avoid problems during what otherwise can be a lengthy integration process (Haspeslagh \& Jemison, 1991). Therefore, we predict:

Hypothesis 2a: Shorter duration of human integration lowers employee resistance following an acquisition.

Task integration speed. While a significant source of value generation from acquisitions comes from gains in efficiency (Siegel \& Simons, 2010) or from implementing superior acquirer 
processes in a target organization (Andrade, Mitchell \& Stafford, 2001; Jovanic \& Rousseau, 2002), task integration interrupts coordination in organizational tasks resulting in coordination problems and conflicts (Shrivastava, 1986). There is also evidence that increased integration speed comes at the expense of necessary support to employees in adapting to new routines (Nemanich \& Vera, 2009). The faster the changes in employees' task environment occur, the less likely social interactions between tasks will also be updated (Weick \& Roberts, 1993) and this disrupts tacit knowledge (Nonaka, 1994). Meanwhile, slower task integration can allow for iteration in the use of routines to facilitate task performance (Bauer et al., 2016; Lavie, Stettner \& Tushman, 2010) and to deepen a common understanding that refines tacit knowledge (Levitt \& March, 1988; Nonaka, 1994) that is likely associated with employee adoption of new procedures. Therefore, we predict:

Hypothesis $2 b$ : Shorter duration of task integration increases employee resistance following an acquisition.

\section{Who Facilitates Change, or Differences in Managerial Roles}

Drawing on the resource-based view, Lamont, King, Maslach, Schwerdtfeger, \& Tienari (2018) suggest that the success of acquisitive growth rests on the quality and quantity of an acquirer's managerial talent. We anticipate that the impact of human and task integration duration is moderated by whether top or middle managers are primarily involved.

When considering top managers, they often need less time for sensemaking than other employees, because they typically initiate acquisitions or they are involved in developing change (Lehn \& Zhao, 2006; Stensaker et al., 2008). However, top management involvement is also needed to initiate changes in combining organizations (Clark, Gioia, Ketchen \& Thomas, 2010), and top managers are visible at acquisition announcement (Hayward \& Hambrick, 1997). For example, top managers can communicate the need behind an acquisition and associated changes 
to reduce employee uncertainty (Giessner, 2011). However, while change can be directed from the top, it still requires sensegiving, or employees understanding change and its intent, as well as its implications. For example, acquisition integration planning only includes a few people at the top of organizations, but integration implementation involves middle managers and employees that require more time for sensemaking (Stensaker et al., 2008; Vaara, 2003).

Middle managers provide a conduit for employees accepting change, but they confront the dual challenge of providing sensegiving and implementing changes they did not design and may only partially understand themselves (Balogun \& Johnson, 2004; Stensaker et al., 2008). Further, implementation of planned changes requires a delicate balance, as employee resistance to change occurs when they perceive change does either too little or too much (Sonenshein, 2010). The need for implementation suggests an increased importance of middle managers during integration that is largely overlooked in acquisition research (Meglio \& Risberg, 2010). Not considering middle managers is an important omission, as research suggests they account for significant differences in firm performance (Mollick, 2012). We anticipate moderating and differential effects of top and middle managers are most evident in how fast human and task integration proceeds.

Human Integration Speed. For human integration, top manager involvement with integration can improve employee retention (Steigenberger, 2017; Zhang et al., 2015). For example, top managers can quickly address concerns associated with a lack of information with a letter to employees that creates a sense of necessity for change (Giessner, 2011; Schweiger et al., 1987; Schweiger \& Denisi, 1991). Still, top managers often employ ambiguity to maintain latitude while outlining common ground without the means to achieve it (Davenport \& Leitch, 2005; Gioia, Nag \& Corley, 2012). However, ambiguity drives sensemaking and it can contribute to shock and perceptions of injustice (cf. Gioia et al., 2012; Yang, Treadway \& Stepina, 2013). 
When human integration is completed quickly, acquiring firm managers are likely to be disproportionally represented in leadership roles (Welch \& Welch, 2005). This can drive disillusionment and resistance from target firm managers and employees that can have more insight in how combined resources can create value (e.g., Chreim, 2015; Chreim \& Tafaghod, 2012; Graebner, 2004). Further, top managers can facilitate faster reaction to problems and maintain momentum (Angwin, 2004). These issues confirm observations that the importance of top managers to human integration matters (Schweiger et al., 1987). Therefore, we predict: Hypothesis 3a: For shorter duration of human integration, greater top management involvement reduces employee resistance.

While top managers can direct reorganization, it requires employee sensemaking to implement (Crevani, Lindgren \& Packendorff, 2010) and this is facilitated by middle managers translating goals into initiatives (Stensaker et al., 2008). Middle manager sensegiving is more likely for issues involving organizational performance and operational effectiveness (Maitlis \& Lawrence, 2007) that are generally degraded during integration. For example, middle managers often provide sensegiving following structural interventions and promote an understanding of change (Balogun \& Johnson, 2004; Steigenberger, 2017). As a result, middle managers adapt integration based on employee concerns (Gates \& Very, 2003). We anticipate middle manager sensemaking constructs meaning that enables sensegiving to employees (Sonenshein, 2010). Huy (2011) recognizes an important role of middle managers in dealing with employee emotions, and we maintain this takes time or it is most evident for longer duration of human integration. Therefore, we predict:

Hypothesis $3 b$ : For longer duration of human integration, greater middle manager involvement reduces employee resistance.

Task Integration Speed. Deciding on organizational structure relates to prescribed changes made by top management (Hinings \& Greenwood, 1988), and for acquisitions identifying 
planned changes needs to be done early (Gates \& Very, 2003). Making the best use of firm resources requires avoiding delays on resource deployment decisions (Brueller, Carmeli \& Drori, 2014) that can involve selecting the best, integrating the best of both, or maintaining separate processes (e.g., Ettenson \& Knowles, 2006). Tasks and procedures separately co-evolve in separate organizations (Penrose, 1959), and recognition of coordination problems during acquisition integration represent a consistent theme in research (e.g., Graebner et al., 2017; Heimeriks et al., 2012; Penrose, 1959; Zorn et al., 2018).

Task integration decisions are best made by top managers, as ambiguity on structure and processes can contribute to political behavior (Vaara, 2003) that is counterproductive for acquisition integration and employee acceptance (Larsson \& Finkelstein, 1999; Monin et al., 2013). Timid integration is a greater risk than integrating too quickly, as only a one-month delay in realizing expected annual savings could reduce the net present value of an acquisition by onefifth (Chanmugam et al., 2005). Therefore, we predict:

Hypothesis 4a: For shorter duration of task integration, greater top management involvement reduces employee resistance.

Following an acquisition, ambiguity from top management can increase political behavior (Vaara, 2003). As a result, a lack of clear strategic decisions from top management on task integration can contribute to political contests (Clougherty \& Duso, 2011) and conflict (Graetz \& Smith, 2010). A lack of direction contributes to middle managers pursuing self-interest that does not align with firm goals (Burgelman, 1994). Political behavior during acquisition integration is often counterproductive (Meyer, 2008) in that it contributes to employee uncertainty and dissatisfaction (Ferris \& Kacmar, 1992; Monin et al., 2013). For example, political behavior and associated employee uncertainty contribute to perceptions of procedural injustice (Yang et al., 2013) that can contribute to employee resistance. Over time, challenges of middle manager 
involvement are likely compounded if it fills a void on the strategic direction of task integration that results in multiple, conflicting efforts from increased political behavior (Clougherty \& Duso, 2011). Clear direction on task integration for middle managers and employees likely mitigates this challenge, and we predict:

Hypothesis 4b: For shorter duration of task integration, greater middle manager involvement lowers employee resistance.

\section{Method}

We used a cross-sectional research design using a survey administered after an acquisition occurred. Acquisitions represent a global phenomenon, but there is limited research on emerging economies (Gubbi et al., 2010) with most research conducted in the U.S. (Meglio \& Risberg, 2011). A gap between practice and research is highly relevant as China ranks only behind the U.S. in the number and value of acquisitions with double digit growth in merger and acquisition activity since 2000 (Gaur, Malhotra \& Zhu, 2013). For example, in 2017, firms in China completed over 13,000 deals worth over $\$ 720$ billion (Bureau Van Dijk, 2018). As a result, we focused on China in developing a sample. In 2017, one of the authors contacted alumni of master degree programs from five Chinese universities describing the intent to study M\&A and asking if: 1) their firm completed an acquisition in the last three years, 2) they were familiar with circumstances before and after the acquisition, and 3) they would participate in the study for a small reward. A total of 145 managers indicated they would participate in the study, but double-

checking that potential respondents were in a company with acquisition activity in the last 3 years resulted in sending the Internet survey to 115 managers. This timeframe is consistent with other acquisition research designed to ensure recollection of events is still sufficient (Ellis, Reus \& Lamont, 2009; Krishnan et al., 1997). From our eligible sample of 115 managers, we received 108 usable responses for a response rate of 93.9 percent. Respondents were primarily middle 
managers that were in a position to best respond, as they represent the interface between top managers and employees (Raes et al., 2011). The use of key informants enables getting information from people knowledgeable about issues unavailable from archival data (Ellis, Reus \& Lamont, 2009).

\section{Research Variable Measurement}

We relied on existing scales with minor modifications to fit our research interest. We did this for two reasons: 1) established scales have already proven reliability and validity, and 2) it makes our results comparable to previous studies (Bryman \& Bell, 2011). All questionnaire items were translated from English into Mandarin and back and by two people to limit translation bias. Prior to sending out the survey, we conducted a pretest to identify unclear terms and to avoid complex and abstract questions that might trigger biases (Doty \& Glick, 1998), with business professionals as well as with academics.

Human Integration. Human integration used three indicators borrowed from Cording et al. (2008). Participants were asked to rate the degree of integration on the three indicators ranging from $1=$ not at all, 4 = partially, and $7=$ fully $(\mathrm{AVE}=0.820 ; \mathrm{CR}=0.932)$.

Task Integration. Task integration used four items referring to specific functions in a scale developed by Zaheer et al. (2013) for an acquisition context. Again, we applied a seven-point Likert scale ranging from $1=$ not at all to $7=$ fully $(\mathrm{AVE}=0.748 ; \mathrm{CR}=0.922)$.

Human Integration Speed. Human integration speed used a single item where the three integration items were named as examples, and this resulted from pretest suggestions to reduce the length of our survey. Integration speed was assessed as duration with a seven-point scale ranging from $1=$ less than 6 months to $7=$ longer than 24 months. 
Task integration speed: We measured task integration speed with the four items developed by Zaheer et al. (2013) using the same scaling for human integration speed (AVE = $0.860 ; \mathrm{CR}=0.961)$.

Employee resistance. Employee resistance used five indicators developed by Giangreco and Peccei (2005). The original measure comes from assessing resistance to change was slightly modified to the acquisition context. The questions asked, whether the target firm personal strongly opposed changes following the acquisition on a scale from $1=$ not at all to $7=$ fully $(\mathrm{AVE}=0.820 ; \mathrm{CR}=0.958)$

Moderators. Top and middle manager responsibility used a single item asking for the responsibility of acquisition implementation and coordination using a seven-point scale.

\section{Control Variables}

We also added several controls for variables frequently used in M\&A research (Hitt et al., 2009). Please note, if not explicitly described, control variables are single item measures. Relative size might have a serious impact on acquisition integration, as larger relative size causes political infighting and conflict (Gomes, Angwin, Weber \& Tarba, 2013), increases coordination efforts (Cording et al., 2008), and reduces the beneficial effects of shared mental models (Dao et al., 2017). Acquisition experience provides an indicator for well-developed acquisition routines and it can influence acquisition integration (Barkema \& Schijven, 2008). Annual sales are an indicator for firm size that leads to increased formalization (Blau et al., 1976) impacting acquisition behavior. Firm growth influences organizational behavior, as firms apply different coordination and control mechanisms in different stages of their lifecycle (e.g. Greiner, 1998). We assessed the average growth three years prior and following the acquisition each with a single item. Finally, an acquirer's structure influences decision-making and behavior, and we applied the organizational structure scale with five indicators developed by Covin and Slevin (1988) with a seven-point 
Likert scale. Due to a low loading we had to delete one item $(\mathrm{AVE}=0.705 ; \mathrm{CR}=0.904)$. To control for corporate forgetting, we assessed acquisitions undertaken in the last three years (Ellis, Reus \& Lamont, 2009).

\section{Results}

In Table 1, we share the descriptive statistics from our survey for firm annual sales, acquisition experience, the type of transaction, and the average industry growth. Our data reflects the objective information on Chinese acquirers. Thus, we assume that sampling bias is not a serious issue for our data. For example, the overall growth rate of China's economy in 2017 was 6.9 percent (Wildau \& Hornby, 2018) and this falls within the highest category of surveyed firms with 32.4 percent of firms reporting industry growth between 6 to 10 percent. --- Insert Table 1 about here ---

For assessing our hypotheses, we used PLS SEM that is suitable for prediction-oriented research, as it maximizes the explained variance of dependent variables (Hair et al., 2012). We examine integration related decisions and their effects on employee resistance with the contingency of management involvement. Thus, we do not concentrate on an overall model fit that is the focus of co-variance based SEM (Barroso, Cepeda \& Rodán, 2010). Instead, we focus on the variance explained of the dependent variable by our independent variables. Additionally, PLS SEM performs well with smaller sample sizes (Hair et al., 2012). For assessing the significance of the proposed relationships, we used the bootstrapping approach with 5,000 runs with the individual-level sign changes option (Henseler, Ringle \& Sinkovics, 2009). For calculating the moderators, we first, standardized the variables and second, chose the product indicator option using all possible pair combinations of the indicators (Chin, Marcolin \& Newsted, 2003). 


\section{Common Method Bias}

Having collected independent and dependent variables at a single point in time from a single respondent, common method bias raises concerns for internal validity (Podsakoff et al. 2003; 2012). In considering potential impacts of common method bias, we took a-priori steps to mitigate it and then performed post-hoc analysis to detect its presence.

A-priori we took multiple measures to mitigate or minimize the potential for common method bias. First, while the tendency to agree (Baumgartner \& Steenkamp, 2001) and the likelihood of non-differentiated answers (Krosnick, 1999) can lead to problems if the task exceeds the cognitive abilities of the respondents, we assume that our respondents are welleducated specialists and able to answer the questions accurately. Second, our respondents are managers with limited time resources, but they were still willing to fill out the questionnaire. Consistent with informal feedback, we also assume that the respondent interest in the survey avoided problems from satisfying and stylistic responses (Krosnick, 1999). Third, as acquisition failure is quite common (King et al., 2004), we assume that social desirability is not a serious issue for our data (Podsakoff et al., 2012). We also avoided complex and ambiguous questions from feedback on a pretest (Doty \& Glick, 1998), used latent variable measures (Harrison, McLaughlin \& Coalter, 1996), and changed the scale direction (e.g. for speed of integration) to minimize response patterns. Still, the sources of method variance might differ from measure to measure (Spector et al., 2018).

Post-hoc we followed advice of Podsakoff and colleagues (2003) and used the guidelines developed by Liang, Saraf, Hu, and Xue (2007) to introduce a common method factor in our PLS model to assess the relationship between the substantive factor and the method factor. The ratio between method factor loadings and substantive factor loadings is 1 to 127 . As a result, we conclude that common method bias is not a serious concern for our data, see Appendix A. 


\section{Measurement Models}

In assessing our model, we followed the two steps recommended by Hulland (1999), involving: 1) the assessment of our measurement models, and 2) the assessment of the relationships among the constructs. In a first step, we assessed our measurement models according to factor loadings (that should exceed a value of 0.7 ), average variance extracted (AVE) with a minimum threshold of 0.5 , and composite reliability (CR) (that should exceed 0.7). Based on the analysis, we conclude that construct reliability and validity is apparent as all values apart from one item of the structure scale exceed the required thresholds, see Appendix B. In a second step, we assessed the discriminant validity of our variables with indicator cross-loadings (Henseler et al., 2009; Hulland, 1999) and on construct level with the Fornell-Larcker criterion (Fornell \& Larcker, 1981). The analyses reveal no serious issues (see Appendices C and D), and we hold that discriminant validity is established.

\section{Hypothesis Testing}

Figure 2 shows our results. Hypothesis 1a predicts that human integration reduces employee resistance following an acquisition, and our results suggest the path is significant and negative ( $\beta$ $=-0.306 ; \mathrm{p}=0.063)$. For hypothesis $1 \mathrm{~b}$, we find statistical support that task integration triggers employee resistance $(\beta=0.261 ; p=0.093)$. The relationship between human integration decisions and duration of human integration is not significant $(B=-.216 ; p=0.136)$, but the negative sign indicates that firms try to pursue human integration quickly. Additionally, shorter duration of human integration does not influence employee resistance, as suggested in hypothesis $2 \mathrm{a}(ß=-.180 ; \mathrm{p}=0.144)$. However, we find that greater task integration is associated with faster task integration $(B=-0.356 ; p=0.024)$, but slower task integration speed triggers employee resistance $(B=0.301 ; p=0.047)$. This result suggests partial mediation, as the direct effect of task integration remains partially significant $(\mathrm{p}<.10)$. For assessing partial mediation, we 
estimate direct, indirect, and total effects simultaneously to mitigate potential biases occurring in traditional step-wise approaches (MacKinnon et al., 2002; Nitzl et al., 2016). To avoid the necessity of distributional assumptions (Preacher \& Hayes, 2004; 2008), we analyzed the bias corrected confidence intervals (Zhao et al., 2010) that are more robust than pseudo t-values (MacKinnon et al., 2004). We find that 0 is not included in the bias corrected confidence intervals of the indirect effect (lower bound $=-0.382$; upper bound $=-0.006$ ), and the results suggest a partial mediation. We also find that human integration decisions and task integration speed, as well as task integration decisions and human integration speed, are not related to each other suggesting that managers consider them distinct.

--- Insert Figure 2 about here ---

Figure 3 helps to interpret the results for Hypotheses 3a and 3b. Hypothesis 3a argues that greater top management involvement is beneficial in cases of faster human integration, and it is partially supported $(B=0.150 ; p=0.095)$. A graph of the interaction shows low top management involvement with shorter duration (faster) human integration is associated with greater employee resistance. By comparison, high middle manager involvement for longer duration (slower) human integration is associated with significantly lower employee resistance $(\beta=-0.201 ; p=0.045)$, supporting hypothesis $3 \mathrm{~b}$. Both results support our premise of differential effects for manager involvement for human integration speed.

--- Insert Figure 3 about here ---

Figure 4 helps to interpret the results for hypotheses $4 \mathrm{a}$ and $4 \mathrm{~b}$. While task integration speed increases employee resistance $(\beta=0.301 ; p=0.047)$, we find that top and middle manager involvement have different moderating effects. While the effects of greater top management involvement largely do not differ for changes in duration of task integration, low top management involvement is associated with greater employee resistance for longer duration (slower) task 
integration $(B=-.290 ; p=0.045)$. This finding contradicts expectations for hypothesis $4 a$, as employee resistance is largely constrained to cases of longer duration (slower) task integration and low top manager involvement. For hypothesis $4 b$, we find partial support for a moderating impact of middle management involvement on the relationship between task integration duration and employee resistance. While middle manager involvement reduces employee resistance in cases of shorter duration (faster) task integration, middle manager involvement increases employee resistance for high duration (slower) task integration $(\beta=0.195 ; p=0.087)$. While not matching all our expectations, these results do support our premise of differential effects for top and middle manager involvement for task integration duration.

--- -Insert Figure 4 about here ---

Some of our controls also have significant impacts on our research model. While increasing annual sales $(B=0.178 ; p=0.075)$ and flexible acquirer structures $(B=0.185 ; p=$ 0.048) slow down task integration, rapid firm growth $(\beta=-0.179 ; \mathrm{p}=0.096)$ and increased relative size (acquisition of larger target) lead to faster task integration $(B=-0.147 ; p=0.076$ ). The latter result suggests faster implementation to reduce redundancy, and the combined significance of these controls is consistent with firms experiencing formalization (Blau et al., 1976) and pursuing task integration quickly to realize synergies at the expense of employee resistance.

\section{Discussion}

Research on acquisitions has long been concerned about a short-sighted focus on functional integration without considering its effects on employees (Cartwright \& Cooper, 1993), even though it is known to contribute to acquisition failure (Larsson \& Finkelstein, 1999). The result has been an increased focus on integration decisions, or questioning what to integrate. In contrast, when or the speed integration decisions are implemented and who leads integration has received 
surprisingly little attention (Meglio et al., 2015). We develop how considering when integration takes place with agency in the integration process (who) provides a better understanding of employee resistance to acquisition integration. Our study supports and expands theory on sensemaking (Weick, 1995) to outline when human and task integration happens and who leads associated efforts matters, or it begins to explain employee resistance to acquisition integration. Beyond demonstrating different roles for top and middle management, our findings elaborate theory on integration speed or a temporal perspective in acquisitions (Angwin, 2004) and sensemaking (Weick, 1995).

\section{Research Implications}

At a general level, our findings support established research that integration can stir negative sentiments and even employee resistance to acquisition integration (e.g. Fried et al., 1996; Larsson \& Finkelstein, 1999). For instance, we find task integration increases employee resistance while the opposite is true for human integration. We also demonstrate increases in resistance can be mitigated by considering human integration. This supports prior research demonstrating active efforts, such as increasing organizational identification, can mediate unwanted effects following acquisitions (Cho et al., 2014; Seo \& Hill, 2005).

Further, attending to what changes and to the sequence of change (when) matters in an acquisition (e.g., Haspeslagh \& Jemison, 1991), as well as who is involved, can enlighten theoretical expectations derived from insights in applying sensemaking to acquisition research. For instance, Pickering and colleagues (2017) find forceful and fast integration by top managers may lead to reduced client focus among employees, and our findings elaborate and provide nuance to this insight. For example, top manager involvement reduces employee resistance to task integration, especially when conducted slowly. However, low top manager involvement increases employee resistance during low duration (faster) human integration. By comparison, high middle 
manager involvement reduces employee resistance for low duration (faster) task integration but increases employee resistance for low duration (faster) human integration. This matches expectations that managers are responsible for acquisition integration (e.g. Larsson \& Finkelstein, 1999), but our results demonstrate differential impacts for who is involved and when. Meanwhile, our focus on temporal considerations does not reveal a significant relationship between speed of human integration and employee resistance. One potential explanation is that task integration 'trumps' efforts on the 'human' or soft side of integration (Cartwright \& Cooper, 1995) in predicting employee resistance. Resistance can go beyond a lack of enthusiasm or indifference for the integration, and it is possible early managerial interventions can avoid more serious employee resistance.

Additionally, our results have theoretical implications for sensemaking research. Our findings suggest greater middle management involvement with slow human integration and fast task integration can reduce employee resistance. While not specifically examined by us, this suggests that middle managers play a role in sensegiving during human integration. While our results are consistent with sensemaking explaining acquisition outcomes (e.g. Vaara, 2003), we also extend current knowledge of sensemaking and acquisition integration. Specifically, our findings suggest that sensemaking is not a passive process, or our results support that managers influence employee reactions to change (e.g., Monin et al., 2013; Gioia \& Chittipeddi, 1991; Steigenberger, 2017). Further, we underscore the need for managerial sensemaking and sensegiving in examining organizational change (Gioia \& Chittipeddi, 1991), such as an acquisition (Clark et al., 2010), by outlining how top and middle managers play different roles toward human and task integration. Overall, our research suggests that acquisitions are an important area for sensemaking research. 


\section{Managerial Implications}

We confirm that acquisitions represent a means for developing economies to gain access to resources and compete on a global stage; however, the success of meeting acquisition goals requires avoiding active employee resistance. Thus, for top managers that face conflict with a target firm and its managers and employees, our results confirm the importance of organizational justice and behavior consistent with implicit contracts (Cording et al., 2014). Further, top managers need to consider middle managers and enable them to help address employee resistance during the acquisition process by involving them in planning longer human integration and giving them clear direction in executing task integration quickly.

While acquisition research has extensively examined potential sources of failure and success, only a handful of acquisition studies have paid explicit attention to unraveling the underlying microfoundations of acquisition outcomes (e.g., Angwin, Paroutis, \& Connell, 2015; Friedman, Carmeli, Tishler \& Shimizu, 2016). Further, as noted by Brueller, Carmeli \& Markman (2018), existing knowledge tends to leave processes underlying acquisitions and postacquisition integration unexplored. For example, human resource (HR) concerns are often overlooked to the detriment of acquisition integration (Meglio et al., 2015; Vaara, 2003). Similarly, Bagdadli, Hayton and Perfido (2014), as well as Weber and Tarba (2010), suggest that acquirers need appropriate HR practices for post-merger integration. Additionally, Graebner, Heimeriks, Huy and Vaara (2017) highlight the need of better understanding of post-acquisition integration with research opportunities on temporality, decision-making, and practices.

Our study probes agency in acquisition integration and presents an opportunity for acquisition research to examine separate roles at different managerial layers. For example, Teerikangas and colleagues (2011) demonstrate middle managers contribute to acquisition performance by reducing value leakage and increasing value added. We clarify this insight and 
demonstrate that fast task integration managed by middle managers reduces employee resistance, while the opposite is true for human integration. We attribute this to political behavior emerging during slower task integration (i.e., Clougherty \& Duso, 2011). A similar effect does not appear with greater top management involvement in task integration, making us conclude involvement of top managers is associated with procedural justice (Yang et al., 2013).

\section{Limitations and Future Research}

While we balance a heavy Western bias in acquisition research with a sample of managers at Chinese firms, context may influence our results. For example, observations suggest acquirers in developed nations apply a long-term perspective and a more deliberate approach to integration (Kumar, 2009). Still, Khan and colleagues (2018) suggest that Chinese expatriate managers tend to view local regulations in a target country as an obstacle to efficiency. The Chinese government also influences acquisitions with through state ownership (Chen \& Young, 2010). While government influence likely exists across our sample, we do not control for the level of state ownership. Further, the effects might be different for countries with strong labor protection, as employees do not need to fear dramatic changes (Bauer et al., 2018; Homburg \& Bucerius, 2006). The combined implication of limitations associated with our sample is that additional research examining identified relationships needs to test the generalizability of our findings to other contextual or institutional settings.

Research also needs to examine relationships between employee resistance and acquisition performance. It is likely that avoiding active employee resistance is necessary, but active employee support may not be needed for acquisition success, especially if integration is not an acquirer's goal. Improving temporal impacts in acquisitions also requires a better appreciation of processes and an understanding of the extent that tasks can be performed in parallel. 
Another opportunity is more closely aligning acquisition research with organizational change (King et al., 2018). For example, Amis and colleagues (2004) outline a consideration of the pace, sequence and linearity of change can help transform organizations. While we examine the duration (speed) of human and task integration, this stops short of other relevant considerations that are just beginning to be considered by acquisition research. For example, the degree of change also needs to be considered with the time to implement it, and the precedence of human and task integration (Bauer et al., 2016). Additionally, most acquisition research considers an acquisition in isolation, and the pace of acquisitions and other changes in combining organizations is just beginning to be considered (Zorn et al., 2018). Further, our research design is cross-sectional and our analysis stops short of examining the linearity of change and causation. As a result, reciprocal relationships among our study variables is possible (Latack et al., 1995), or our findings depend on statistical conclusion validity (Sussman \& Robertson, 1986). Each of these considerations represent clear opportunities for additional research. In closing, we hope that our ideas lead to additional research on manager effects on employee resistance during acquisition integration. 


\section{References}

Amis, J., Slack, T., \& Hinings, C. (2004). The pace, sequence, and linearity of radical change. Academy of Management Journal, 47(1), 15-39.

Andrade, G., Mitchell, M., \& Stafford, E. (2001). New evidence and perspectives on mergers. Journal of Economic Perspectives, 15(2), 103-120.

Angwin, D. (2004). Speed in M\&A Integration: The first 100 days, European Journal of Management, 22, 418-430.

Angwin, D., Paroutis, S., \& Connell, R. (2015). Why good things Don't happen: The microfoundations of routines in the M\&A process. Journal of Business Research, 68(6), 13671381.

Astrachan, J. (1995). Organizational departures: The impact of separation anxiety as studied in a mergers and acquisitions simulation. Journal of Applied Behavioral Science, 31, 31-50.

Bagdadli, S., Hayton, J., \& Perfido, O. (2014). Reconsidering the role of HR in M\&As: What can be learned from practice. Human Resource Management, 53, 1005-1025.

Balogun, J., \& Johnson, G. (2004). Organizational restructuring and middle manager sensemaking, Academy of Management Journal, 47, 523-549.

Barkema, H., \& Schijven, M. (2008). How firms learn to make acquisitions? A review of past research and an agenda for the future, Journal of Management, 34(3), 594-634.

Barroso, C., Cepeda, G., \& Roldán, J. (2010). Applying maximum likelihood and PLS on different sample sizes: Studies on SERVQUAL model and employee behavior model. In V. Esposito Vinzi, W. W. Chin, J. Henseler, \& H. Wang (Eds.), Handbook of partial least squares (pp. 427-448). Berlin, Germany: Springer.

Bauer, F., King, D., \& Matzler, K. (2016). Speed of acquisition integration: Separating the role of human and task integration. Scandinavian Journal of Management, 32(3): 150-165.

Bauer, F., Schriber, S., Degischer, D., \& King, D. (2018). Contextualizing speed and cross-border acquisition performance: Labor market flexibility and efficiency effects, Journal of World Business, 53: 290-301.

Baumgartner, H., \& Steenkamp, J. (2001). Response styles in marketing research: A crossnational investigation. Journal of Marketing Research, 38(2), 143-156.

Birkinshaw, J., Bresman, H., \& Hakanson, L. (2000). Managing the post-acquisition integration process: How the human integration and task integration processes interact to foster value creation. Journal of Management Studies, 37, 395-425.

Blau, P., Falbe, C., McKinley, W., \& Tracy, P. (1976). Technology and organization in manufacturing, Administrative Science Quarterly, 21(1), 20-40.

Brueller, N., Carmeli, A., \& Drori, I. (2014). How do different types of mergers and acquisitions facilitate strategic agility? California Management Review, 56(3), 39-57.

Brueller, N., Carmeli, A., \& Markman, G. (2018). Linking merger and acquisition strategies to postmerger integration: a configurational perspective of human resource management. Journal of Management, 44, 1793-1818.

Bryman, A., \& Bell, E. (2011). Business Research Methods, third ed. Oxford University Press, Oxford.

Buono, A., \& Bowditch, J. (2003). The human side of mergers and acquisitions: Managing collisions between people, cultures, and organizations. Washington, D.C: Beard Books.

Bureau van Dijk. (2018). Global M\&A review 2017: http://www.mandaportal.com/getattachment/65311440-5493-4b45-9747e0c6f3cb0579/Global-M-A-Review,-2017 
Burgelman, R. (1994). Fading memories: A process theory of strategic business exit in dynamic environments. Administrative Science Quarterly, 24-56.

Cartwright, S. \& Cooper, C. (1993). The psychological impact of merger and acquisition on the individual: A study of Building Society managers. Human Relations, 46, 327-347.

Cartwright, S. \& Cooper, C. (1995). Organizational marriage: "hard" versus "soft" issues? Personnel Review, 24(3), 32-42.

Chanmugam, R., Shill, W., Mann, D., Ficercy, K., \& Pursche, B. 2005. The intelligent clean room: Ensuring value capture in mergers and acquisitions, Journal of Business Strategy, 26(3): 43-49.

Chen, Y., \& Young, M. (2010). Cross-border mergers and acquisitions by Chinese listed companies: A principal-principal perspective. Asia Pacific Journal of Management, 27(3), 523-539.

Chin, W., Marcolin, B., \& Newsted, P. (2003). A partial least squares latent variable modeling approach for measuring interaction effects: Results from a Monte Carlo simulation study and an electronic-mail emotion \& adoption study. Information Systems Research, 14(2), 189-2017.

Cho, B., Lee, D., \& Kim, K. (2014). How does relative deprivation influence employee intention to leave a merged company? The role of organizational identification. Human Resource Management, 53(3), 421-443.

Chreim, S. (2015). The (non) distribution of leadership roles: Considering leadership practices and configurations. Human Relations, 68(4), 517-543.

Chreim, S., \& Tafaghod, M. (2012). Contradiction and sensemaking in acquisition integration, Journal of Applied Behavioral Science, 48(1), 5-32.

Clark, S. M., Gioia, D. A., Ketchen, D. J., \& Thomas, J. B. (2010). Transitional identity as a facilitator of organizational identity change during a merger. Administrative Science Quarterly, 55(3), 397-438.

Clougherty, J., \& Duso, T. (2011). Using rival effects to identify synergies and improve merger typologies, Strategic Organization, 9, 310-335.

Colman, H., \& Lunnan, R. (2011). Organizational identification and serendipitous value creation in post-acquisition integration. Journal of Management, 37(3), 839-860.

Colman, H., \& Rouzies, A. (2018). Postacquisition boundary spanning: A relational perspective on integration. Journal of Management, 0149206318759400.

Cooke, F., \& Huang, K. (2011). Postacquisition evolution of the appraisal and reward systems: A study of Chinese IT firms acquired by US firms. Human Resource Management, 50(6), 839-858.

Cording, M., Christmann, P., \& King, D. (2008). Reducing causal ambiguity in acquisition integration: Intermediate goals as mediators of integration decisions and acquisition performance, Academy of Management Journal, 51(4), 744-767

Cording, M., Harrison, J., Hoskisson, R., \& Jonsen, K. (2014). Walking the talk: A multistakeholder exploration of organizational authenticity, employee productivity, and post-merger performance, Academy of Management Perspectives, 28(1), 38-56

Covin, J., \& Slevin, D. (1988). The influence of organization structure on the utility of an entrepreneurial top management style, Journal of Management Studies, 25(3), 217-234.

Crevani, L., Lindgren, M., \& Packendorff, J. (2010). Leadership, not leaders: On the study of leadership as practices and interactions, Scandinavian Journal of Management, 26, 77-86.

Cullinan, G., Le Roux, J., \& Weddigen, R. (2004). When to walk away from a deal, Harvard Business Review, 82(4), 96-104 
Dao, M., Strobl, A., Bauer, F., \& Tarba, S. (2017). Triggering innovation through mergers and acquisitions: The role of shared mental models. Group and Organization Management, 42(23), 195-236.

Davenport, S., \& Leitch, S. (2005). Circuits of power in practice: Strategic ambiguity as delegation of authority. Organization Studies, 26(11), 1603-1623.

Doty, D., \& Glick, W. (1998). Common methods bias: does common methods variance really bias results? Organizational Research Methods, 1(4), 374-406.

Drori, I., Wrzesniewski, A., \& Ellis, S. (2011). Cultural clashes in a "merger of equals": The case of high-tech start-ups. Human Resource Management, 50, 625-649.

Edwards, M. R., \& Edwards, T. (2013). Employee responses to changing aspects of the employer brand following a multinational acquisition: a longitudinal study. Human Resource Management, 52(1), 27-54.

Edwards, T., \& Edwards, M. R. (2015). Perceptions of employee voice and representation in the post-acquisition period: Comparative and longitudinal evidence from an international acquisition. Human Relations, 68(1), 131-156.

Eisenhardt, K. Furr, N., \& Bingham, C. (2010). Microfoundations of performance: Balancing efficiency and flexibility in dynamic environments. Organization Science, 21(6), 12631273.

Ellis, K., Reus, T., \& Lamont, B. (2009). The effects of procedural and informational justice in the integration of related acquisitions. Strategic Management Journal, 30: 137-161.

Ellis, K., Weber, Y., Raveh, A., \& Tarba, S. (2012). Integration in large, related M\&As: Linkages between contextual factors, integration approaches and process dimensions, European Journal of International Management, 6, 368-394.

Ettenson, R., \& Knowles, J. (2006). Merging the brands and branding the merger, Sloan Management Review, 47(4): 39-49.

Ferris, G., \& Kacmar, K. (1992). Perceptions of organizational politics. Journal of Management, 18(1), 93-116.

Fornell C., \& Larcker, D. (1981). Evaluating structural equation models with unobservable variables and measurement error. Journal of Marketing Research, 18, 39-50.

Fried, Y., Tiegs, R., Naughton, T., \& Ashforth, B. (1996). Managers' reactions to a corporate acquisition: A test of an integrative model. Journal of Organizational Behavior, 401-427.

Friedman, Y., Carmeli, A., Tishler, A., \& Shimizu, K. (2016). Untangling micro-behavioral sources of failure in mergers and acquisitions: a theoretical integration and extension. International Journal of Human Resource Management, 27, 2339-2369.

Gates, S., \& Very, P. (2003). Measuring performance during M\&A integration. Long Range Planning, 36, 167-185.

Gaur, A., Malhotra, S., \& Zhu, P. (2013). Acquisition announcements and stock market valuations of acquiring firms' rivals: A test of the growth probability hypothesis in China, Strategic Management Journal, 34, 215-232.

Giangreco, A., \& Peccei, R. (2005). The nature and antecedents of middle manager resistance to change: evidence from an Italian context, International Journal of Human Resource Management, 16(10), 1812-1829.

Giessner, S. (2011). Is the merger necessary? The interactive effect of perceived necessity and sense of continuity on post-merger identification, Human Relations, 64: 1079-1098.

Gill, C. (2012). The role of leadership in successful international mergers and acquisitions: Why Renault-Nissan succeeded and DaimlerChrysler-Mitsubishi failed. Human Resource Management, 51, 433-456. 
Gioia, D., \& Chittipeddi, K. (1991). Sensemaking and sensegiving in strategic change initiation. Strategic Management Journal, 12(6), 433-448.

Gioia, D., Nag, R., \& Corley, K. G. (2012). Visionary ambiguity and strategic change: The virtue of vagueness in launching major organizational change. Journal of Management Inquiry, 21(4), 364-375.

Gomes, E., Angwin, D., Weber, Y., \& Tarba, S. (2013). Critical success factors through the mergers and acquisition process: Revealing pre- and post-M\&A connections for improved performance, Thunderbird International Business Review, 55, 13-35.

Graebner, M. (2004). Momentum and serendipity: How acquired leaders create value in the integration of technology firms. Strategic Management Journal, 25, 751-777.

Graebner, M., Heimeriks, K., Huy, Q., \& Vaara, E. (2017). The process of postmerger integration: A review and agenda for future research. Academy of Management Annals, 11, 1-32.

Graetz, F., \& Smith, A. (2010). Managing organizational change: A philosophies of change approach. Journal of Change Management, 10(2), 135-154.

Greiner, L. (1998). Evolution and revolution as organizations grow. Harvard Business Review, May-June, 3-11.

Gubbi, S., Aulakh, P., Ray, S., Sarkar, M., \& Chittoor, R. (2010). Do international acquisitions by emerging-economy firms create shareholder value? The case of Indian firms, Journal of International Business Studies, 41: 397-418.

Hair, J., Ringle, C., \& Sarstedt, M. (2012). Partial least squares: The better approach to structural equation modeling? Long Range Planning, 45, 312-319.

Hair, J., Sarstedt, M., Ringle, C., \& Mena, J. (2012). An assessment of the use of partial least squares structural equation modeling in marketing research. Journal of the Academy of Marketing Science, 40, 414-433.

Harrison, D., McLaughlin, M., \& Coalter, T. (1996). Context, cognition, and common method variance: psychometric and verbal protocol evidence. Organizational Behavior and Human Decision Processes, 68 (3), 246-261.

Haspeslagh, P., \& Jemison, D. (1991). Managing acquisitions: Creating value through corporate renewal. New York: Free Press.

Hayward, M., \& Hambrick, D. (1997). Explaining the premiums paid for large acquisitions: Evidence of CEO hubris, Administrative Science Quarterly, 42, 103-127.

Heimeriks, K., Schijven, M., \& Gates, S. 2012. Manifestations of higher-order routines: The underlying mechanisms of deliberate learning in the context of postacquisition integration, Academy of Management Journal, 55: 703-726.

Henneberg, S., Naudé, P., \& Mouzas, S. (2010). Sense-making and management in business networks - Some observations, considerations, and a research agenda. Industrial Marketing Management, 39(3), 355-360.

Henseler, J., Ringle, C., \& Sinkovics, R. (2009). Advances in international marketing. Bingley, UK: Emerald Group.

Hinings, C., \& Greenwood, R. (1988). The dynamics of strategic change. Blackwell: New York.

Hitt, M., King, D., Krishnan, H., Makri, M., Schijven, M., Shimizu, K., \& Zhu, H. (2009). Mergers and acquisitions: Overcoming pitfalls, building synergy, and creating value. Business Horizons, 52: 523-529.

Hulland, J. (1999). Use of partial least squares (PLS) in strategic management research: A review of four recent studies, Strategic Management Journal, 20(2), 195-204. 
Huy, Q. (2011). How middle managers' group-focus emotions and social identities influence strategy implementation, Strategic Management Journal, 32, 1387-1410.

Jansen, J., Tempelaar, M., Van den Bosch, F., \& Volberda, H. (2009). Structural differentiation and ambidexterity: The mediating role of integration mechanisms. Organization Science, 20, 797-811.

Jemison, D., \& Sitkin, S. (1986). Corporate acquisitions: A process perspective. Academy of Management Review, 11, 145-163.

Jovanic, B., \& Rousseau, P. (2002). The Q-theory of mergers. American Economic Review, 92(2), 198-204.

Katou, A. A., Budhwar, P. S., \& Patel, C. (2014). Content vs. process in the HRM-performance relationship: An empirical examination. Human Resource Management, 53(4), 527-544.

Khan, Z., Wood, G., Tarba, S. Y., Rao-Nicholson, R., \& He, S. (2018). Human resource management in Chinese multinationals in the United Kingdom: The interplay of institutions, culture, and strategic choice. Human Resource Management. https://doi.org/10.1002/hrm.21935

King, D., Bauer, F., \& Schriber, S. (2018). Mergers and acquisitions: A research overview. Routledge: London, UK.

Krishnan, H., Hitt, M., \& Park, D. (2007). Acquisition premiums, subsequent workforce reductions and post-acquisition performance. Journal of Management Studies, 44: 709732.

Krosnick, J. (1999). Survey research. Annual Review of Psychology, 50(1), 537-567.

Kumar, N. (2009). How emerging giants are rewriting the rules of M\&A. Harvard Business Review, 87(5), 115.

Lamont, B. T., King, D. R., Maslach, D. J., Schwerdtfeger, M., \& Tienari, J. (2018). Integration capacity and knowledge-based acquisition performance. $R \& D$ Management. https://doi.org/10.1111/radm.12336

Larsson, R., \& Finkelstein, S. (1999). Integrating strategic, organizational, and human resource perspectives on mergers and acquisitions: A case survey of synergy realization. Organization Science, 10(1), 1-26.

Latack, J., Kinicki, A., \& Prussia, G. (1995). An integrative process model of coping with job loss. Academy of Management Review, 20(2), 311-342.

Lavie, D., Stettner, U., \& Tushman, M. (2010). Exploration and exploitation within and across organizations, Academy of Management Annals, 4, 109-155.

Lehn, K., \& Zhao, M. (2006). CEO turnover after acquisitions: Are bad bidders fired? Journal of Finance, 61, 1759-1811.

Levitt, B., \& March, J. (1988). Organizational learning. Annual Review of Sociology, 14, 319340.

Liang, H., Saraf, N., Hu, Q., \& Xue, Y. (2007). Assimilation of enterprise systems: The effect of institutional pressures and the mediating role of top management. MIS Quarterly, 31(1), 59-87.

Liu, Y., \& Meyer, K. E. (2018). Boundary spanners, HRM practices, and reverse knowledge transfer: The case of Chinese cross-border acquisitions. Journal of World Business. https://doi.org/10.1016/j.jwb.2018.07.007

MacKinnon, D., Lockwood, C., Hoffman, J., West, S. \& Sheets, V. (2002). A comparison of methods to test mediation and other intervening variable effects. Psychological Methods, $7(1), 83$. 
MacKinnon, D., Lockwood, C., \& Williams, J. (2004). Confidence limits for the indirect effect: Distribution of the product and resampling methods. Multivariate Behavioral Research, 39(1), 99-128.

Maitlis, S., \& Christianson, M. (2014). Sensemaking in organizations: Taking stock and moving forward. Academy of Management Annals, 8(1), 57-125.

Maitlis, S., \& Lawrence, T. B. (2007). Triggers and enablers of sensegiving in organizations. Academy of Management Journal, 50(1), 57-84.

Maitlis, S., \& Sonenshein, S. (2010). Sensemaking in crisis and change: Inspiration and insights from Weick (1988). Journal of Management Studies, 47(3), 551-580.

Marmenout, K. (2010). Employee sensemaking in mergers: How deal characteristics shape employee attitudes. Journal of Applied Behavioral Science, 46(3), 329-359.

Meglio, O., \& Risberg, A. (2010). Mergers and acquisitions-time for a methodological rejuvenation of the field? Scandinavian Journal of Management, 26, 87-95

Meglio, O., \& Risberg, A. (2011). The (mis)measurement of M\&A performance-a systematic narrative literature review, Scandinavian Journal of Management, 27, 418-433.

Meglio, O., King, D., \& Risberg, A. (2015). Improving acquisition performance with contextual ambidexterity. Human Resource Management, 54(S1), 29-43.

Meglio, O., King, D., \& Risberg, A. (2017). Speed in acquisitions: A managerial framework. Business Horizons, 60, 415-425.

Melkonian, T., Monin, P., \& Noorderhaven, N. (2011). Distributive justice, procedural justice, exemplarity, and employees' willingness to cooperate in M\&A integration processes: An analysis of the Air France-KLM merger. Human Resource Management, 50, 809-837.

Meyer, C. (2006). Destructive dynamics of middle management intervention in postmerger processes, Journal of Applied Behavioral Science, 42, 397-419.

Meyer, C. (2008). Value leakages in mergers and acquisitions: Why they occur and how they can be addressed. Long Range Planning, 41(2), 197-224.

Mollick, E. (2012). People and process, suits and innovators: The role of individuals in firm performance, Strategic Management Journal, 33, 1001-1015.

Monin, P., Noorderhaven, N., Vaara, E., \& Kroon, D. (2013). Giving sense to and making sense of justice in postmerger integration. Academy of Management Journal, 56(1), 256-284.

Nemanich, L., \& Vera, D. (2009). Transformational leadership and ambidexterity in the context of an acquisition. Leadership Quarterly, 20, 19-33.

Nitzl, C., Roldan, J., \& Cepeda, G. (2016). Mediation analysis in partial least squares path modeling: Helping researchers discuss more sophisticated models. Industrial Management \& Data Systems, 116(9), 1849-1864.

Nonaka, I. (1994). A dynamic theory of organizational knowledge creation. Organization Science, 5, 14-37.

Paruchuri, S., Nerkar, A., \& Hambrick, D. C. (2006). Acquisition integration and productivity losses in the technical core: Disruption of inventors in acquired companies. Organization Science, 17(5), 545-562.

Penrose, E. (1959). The theory of the growth of the firm. John Wiley: New York.

Pickering, M. (2017). Post-acquisition integration processes in publicly owned professional service companies: Senior professional behaviour and company performance. Journal of Organizational Behavior, 38(7), 950-976.

Podsakoff, P., MacKenzie S., \& Podsakoff N. (2012). Sources of method bias in social science research and recommendations on how to control it. Annual Review of Psychology, 63(1), 539-569. 
Podsakoff, P., MacKenzie, S., Lee, J., \& Podsakoff, N. (2003). Common method biases in behavioral research: A critical review of the literature and recommended remedies. Journal of Applied Psychology, 88(5), 879-903.

Preacher, K. J., \& Hayes, A. F. (2004). SPSS and SAS procedures for estimating indirect effects in simple mediation models. Behavior Research Methods, Instruments, \& Computers, 36(4), 717-731.

Preacher, K. J., \& Hayes, A. F. (2008). Asymptotic and resampling strategies for assessing and comparing indirect effects in multiple mediator models. Behavior Research Methods, 40(3), 879-891.

Rafferty, A., \& Restubog, S. (2010). The impact of change process and context on change reactions and turnover during a merger. Journal of Management, 36, 1309-1338.

Risberg, A. (1997). Ambiguity and communication in cross-cultural acquisitions: Towards a conceptual framework, Leadership and Organization Development Journal, 18(5), 257266.

Rouzies, A., Colman, H. L., \& Angwin, D. (2018). Recasting the dynamics of post-acquisition integration: An embeddedness perspective. Long Range Planning. https://doi.org/10.1016/j.1rp.2018.03.003

Sarala, R., Vaara, E., \& Junni, P. (2017). Beyond merger syndrome and cultural differences: New avenues for research on the "human side" of global mergers and acquisitions (M\&As). Journal of World Business. https://doi.org/10.1016/j.jwb.2017.10.001

Schweiger, D., \& Denisi, A. (1991). Communication with employees following a merger: A longitudinal field experiment. Academy of Management Journal, 24, 110-135.

Schweiger, D., Ivancevich, J., \& Power, F. (1987). Executive actions for managing human resources before and after acquisition, Academy of Management Executive, 1(2), 127-138.

Searle, R., \& Ball, K. (2004). The development of trust and distrust in a merger. Journal of Managerial Psychology, 19(7), 708-721.

Seo, M., \& Hill, S. (2005). Understanding the human side of merger and acquisition, Journal of Applied Behavioral Science, 41, 422-443.

Shi, W., \& Prescott, J. (2011). Sequence patterns of firms' acquisition and alliance behaviour and their performance implications. Journal of Management Studies, 48(5), 1044-1070.

Shi, W., \& Prescott, J. (2012). Rhythm and entrainment of acquisition and alliance initiatives and firm performance: A temporal perspective. Organization Studies, 33(10), 1281-1310.

Shrivastava, P. (1986). Postmerger integration. Journal of Business Strategy, 7(1), 65-76.

Siegel, D., \& Simons, K. (2010). Assessing the effects of mergers and acquisitions on firm performance, plant productivity, and workers: New evidence from matched employeremployee data, Strategic Management Journal, 31, 903-916.

Sonenshein, S. (2010). We're changing - or are we? Untangling the role of progressive, regressive, and stability narratives during strategic change implementation, Academy of Management Journal, 53, 477-512.

Spector, P., Rosen. C., Richardson, H., Williams, L., \& Johnson, R. (2018). A new perspective on method variance: A measure-centric approach, Journal of Management. 0149206316687295

Stahl, G., Angwin, D., Very, P., Gomes, E., Weber, Y., Tarba, S., Noorderhaven, N., Benyamini, H., Boukenooghe, D., Chreim, S., Durand, M., Hassett, M., Kokk G., Mendenhall, M., Mirc, Nicola, Miska, C., Park, K., Reynolds, N., Rouzies, A., Sarala, R., Seloti, S., Sondergaard, M., \& Yildiz, H. (2013). Sociocultural integration in mergers and 
acquisitions: Unresolved paradoxes and directions for future research, Thunderbird International Business Review, 55, 333-356.

Stahl, G., Larsson, R., Kremershof, I., \& Sitkin, S. (2011). Trust dynamics in acquisitions: A case survey. Human Resource Management, 50(5), 575-603.

Steigenberger, N. (2017). The challenge of integration: A review of the M\&A integration literature, International Journal of Management Reviews, 19, 408-431.

Stensaker, I., Falkenberg, J., \& Grønhaug, K. (2008). Implementation activities and organizational sensemaking. Journal of Applied Behavioral Science, 44(2), 162-185.

Summers, J., Humphrey, S., \& Ferris, G. (2012). Team member change, flux in coordination, and performance: Effects of strategic core roles, information transfer, and cognitive ability. Academy of Management Journal, 55(2), 314-338.

Sussman, M. \& Robertson, D. (1986). The Validity of Validity: An Analysis of Validation Study Designs. Journal of Applied Psychology, 71(3), 461-468.

Teerikangas, S., Véry, P., \& Pisano, V. (2011). Integration managers' value-capturing roles and acquisition performance. Human Resource Management, 50(5), 651-683.

Ullrich, J., \& van Dick, R. (2007). The group psychology of mergers \& acquisitions: Lessons from the social identity approach. Advances in Mergers and Acquisitions, 6, 1-15.

Ullrich, J., Wieseke, J., \& van Dick, R. (2005). Continuity and change in mergers and acquisitions: A social identity case study of a German industrial merger, Journal of Management Studies, 42: 1549-1569.

Uzelac, B., Bauer, F., Matzler, K., \& Waschak, M. (2016). The moderating effects of decisionmaking preferences on M\&A integration speed and performance. International Journal of Human Resource Management, 27(20), 2436-2460.

Vaara, E. (2003). Post-acquisition integration as sensemaking: Glimpses of ambiguity, confusion, hypocrisy, and politicization. Journal of Management Studies, 40, 859-894.

Vermeulen, F. (2005). How acquisitions can revitalize companies. Sloan Management Review, 46(4), 45-51.

Weber, Y., \& Tarba, S. (2010). Human resource practices and performance of mergers and acquisitions in Israel. Human Resource Management Review, 20, 203-211.

Weick, K. (1995). Sensemaking in Organizations. Sage: Thousand Oaks, CA.

Weick, K., \& Roberts, K. (1993). Collective mind in organizations: Heedful interrelating on flight decks, Administrative Science Quarterly, 38, 357-381.

Welch, J., \& Welch, S. (2005). Winning. HarperCollins: New York.

Wildau, G., \& Hornby, L. (2018). China's 2017 economic growth fastest in two years, Financial Times, 18 January: https://www.ft.com/content/9bf532a8-66de-37bf-b515-03589957ada4

Yang, J., Treadway, D., \& Stepina, L. (2013). Justice and politics: Mechanisms for the underlying relationships of role demands to employee's satisfaction and turnover intentions, Journal of Applied Social Psychology, 43, 1624-1635.

Zaheer, A., Castaner, X., \& Souder, D. (2013). Synergy sources, target autonomy, and integration in acquisitions. Journal of Management, 39(3), 604-632.

Zhang, J., Ahammad, M., Tarba, S., Cooper, C., Glaister, K., \& Wang, J. (2015). The effect of leadership style on talent retention during merger and acquisition integration: Evidence from China. International Journal of Human Resource Management, 26(7), 1021-1050.

Zhao, X., Lynch, J., \& Chen, Q. (2010). Reconsidering Baron and Kenny: Myths and truths about mediation analysis. Journal of Consumer Research, 37(2), 197-206. 
Zhou, A. J., Fey, C., \& Yildiz, H. E. (2018). Fostering integration through HRM practices: An empirical examination of absorptive capacity and knowledge transfer in cross-border M\&As. Journal of World Business.

Zorn, M., Sexton, J., Bhussar, M., \& Lamont, B. (2018). Unfinished Business: Nested Acquisitions, Managerial Capacity, and Firm Performance. Journal of Management, 0149206317708855. 
Table 1: Sample descriptive statistics

\begin{tabular}{lclc}
\hline Annual Sales & in $\%$ & Acquisition Experience & in $\%$ \\
< 25 Million & 15.7 & none & 2.8 \\
25 M. - 49 M. & 7.4 & $1-2$ & 60.2 \\
50 M. - 99 M. & 1.9 & $3-4$ & 22.2 \\
100 M. - 249 M. & 5.6 & $5-6$ & 7.4 \\
250 M. - 499 M. & 18.5 & $7-8$ & 0.9 \\
500 M. - 1.000 M. & 14.8 & $>8$ & 6.5 \\
>1.000 Milion & 36.1 & & \\
& & & \\
Transaction Type & in $\%$ & Industry Growth & in $\%$ \\
Horizontal & 45.4 & $<-15 \%$ & 2.8 \\
Vertical & 23.1 & $-15 \%--5 \%$ & 5.6 \\
Conglomerate & 31.5 & $-4 \%-+/-0 \%$ & 5.6 \\
& & $1 \%-5 \%$ & 22.2 \\
& & $6 \%-10 \%$ & 32.4 \\
& & $11 \%-20 \%$ & 19.4 \\
& & $21 \%-30 \%$ & 6.5 \\
\end{tabular}




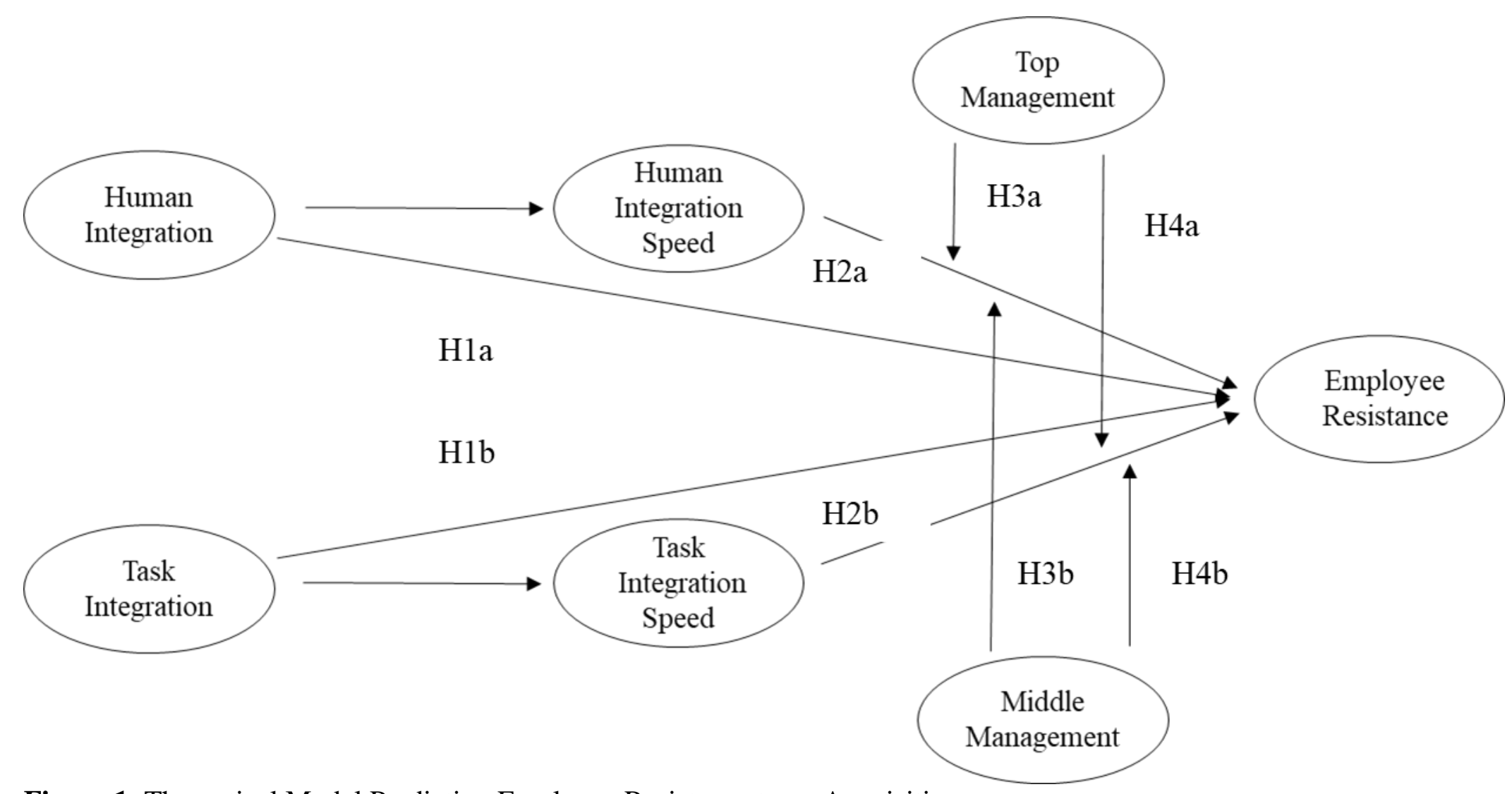

Figure 1: Theoretical Model Predicting Employee Resistance to an Acquisition 


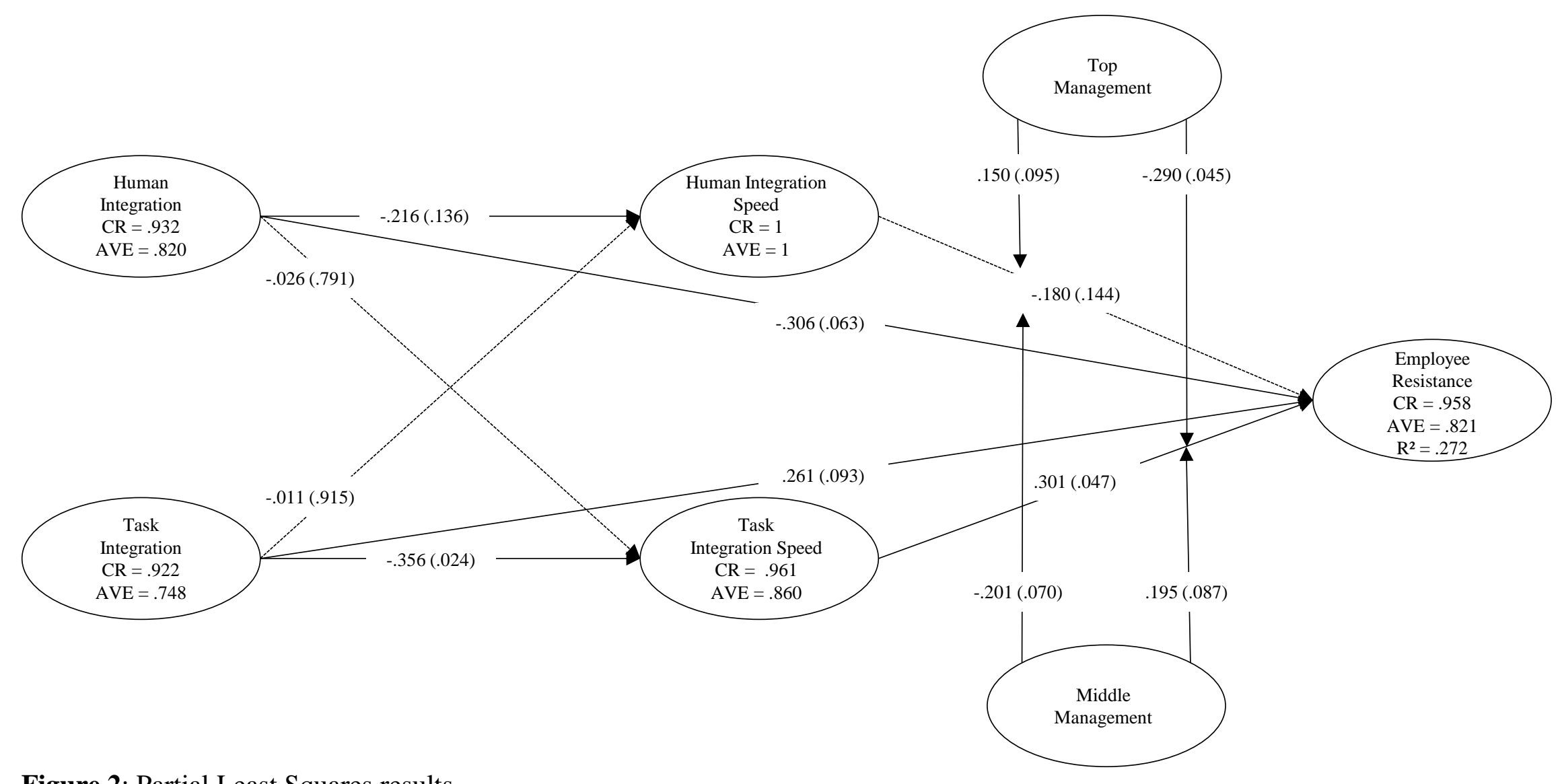

Figure 2: Partial Least Squares results 

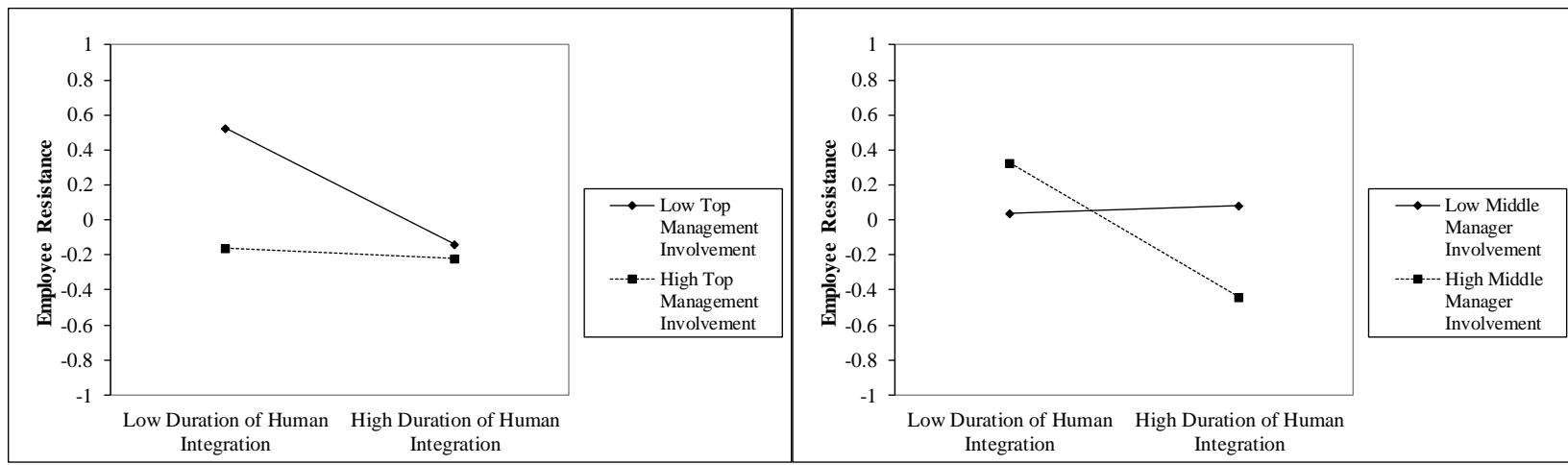

Figure 3: Human Integration Speed and Management Level interaction on Employee Resistance 


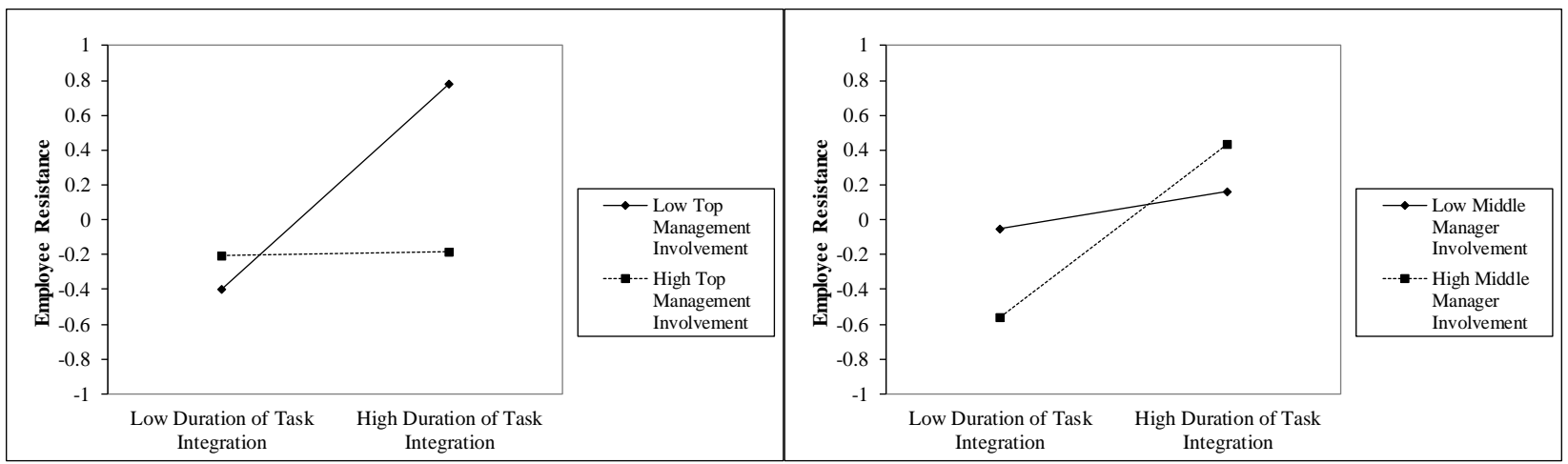

Figure 4: Task Integration Speed and Management Level interaction on Employee Resistance 
Appendix A: Common Method Bias Analysis

\begin{tabular}{|c|c|c|c|c|c|c|}
\hline Construct & Indicator & $\begin{array}{l}\text { Substantive } \\
\text { Factor R1 }\end{array}$ & $\mathrm{R}^{2}$ & $\begin{array}{l}\text { Method } \\
\text { Factor } \\
\text { Loading R2 }\end{array}$ & $\mathrm{R} 2^{2}$ & \\
\hline \multirow[t]{3}{*}{ Human Integration } & HI1 & 0,849 & 0,721 & 0,096 & & 0,009 \\
\hline & HI2 & 0,868 & 0,753 & 0,046 & & 0,002 \\
\hline & HI3 & 0,892 & 0,796 & $-0,149$ & & 0,022 \\
\hline \multirow[t]{4}{*}{ Functional Integration } & FI1 & 0,731 & 0,534 & 0,14 & & 0,020 \\
\hline & FI2 & 0,971 & 0,943 & $-0,18$ & & 0,032 \\
\hline & FI3 & 0,916 & 0,839 & $-0,11$ & & 0,012 \\
\hline & FI4 & 0,857 & 0,734 & 0,043 & & 0,002 \\
\hline $\begin{array}{l}\text { Human Integration Speed } \\
\text { Functional Integration }\end{array}$ & HID1 & 1 & 1,000 & 0 & & 0,000 \\
\hline \multirow[t]{4}{*}{ Speed } & FID1 & 0,845 & 0,714 & $-0,106$ & & 0,011 \\
\hline & FID2 & 0,98 & 0,960 & 0,091 & & 0,008 \\
\hline & FID3 & 0,926 & 0,857 & $-0,033$ & & 0,001 \\
\hline & FID4 & 0,96 & 0,922 & 0,05 & & 0,003 \\
\hline \multirow[t]{5}{*}{ Resistance } & $\mathrm{R} 1$ & 0,895 & 0,801 & $-0,06$ & & 0,004 \\
\hline & $\mathrm{R} 2$ & 0,869 & 0,755 & 0,048 & & 0,002 \\
\hline & $\mathrm{R} 3$ & 0,916 & 0,839 & 0,021 & & 0,000 \\
\hline & $\mathrm{R} 4$ & 0,928 & 0,861 & 0,03 & & 0,001 \\
\hline & R5 & 0,922 & 0,850 & 0 & & 0,000 \\
\hline Top Management & TM1 & 1 & 1,000 & 0 & & 0,000 \\
\hline Middle Management & MM1 & 1 & 1,000 & 0 & & 0,000 \\
\hline Relative Size & RS1 & 1 & 1,000 & 0 & & 0,000 \\
\hline Experience & E1 & 1 & 1,000 & 0 & & 0,000 \\
\hline \multirow[t]{4}{*}{ Structure } & St1 & 0,846 & 0,716 & $-0,135$ & & 0,018 \\
\hline & St2 & 0,883 & 0,780 & $-0,092$ & & 0,008 \\
\hline & St3 & 0,819 & 0,671 & 0,158 & & 0,025 \\
\hline & St4 & 0,873 & 0,762 & 0,074 & & 0,005 \\
\hline Decentralized & DD1 & 1 & 1,000 & 0 & & 0,000 \\
\hline Growth post & GP & 1 & 1,000 & 0 & & 0,000 \\
\hline Growth prior & GPR & 1 & 1,000 & 0 & & 0,000 \\
\hline Sum & & & 23,809 & & & 0,187 \\
\hline Ratio & & & 127 & & & 1 \\
\hline
\end{tabular}


Appendix B: Psychometric Properties of the Scales

Composite

Reliability/Cronbach's

\section{Construct}

Human Integration

Human Integration Speed

Task Integration Speed

\section{Resistance}

Top Management

Middle Management

Annual Sales

Growth Prior

Growth Post

Decentralized Decisions
Indicators

Please indicate the degree to which the following items or areas were integrated

(1, "not at all"; 7, "completely").

Organizational Structure

Organizational Culture

Personnel Management Practices (Human Resources)

Please indicate the degree to which the following items or areas were integrated

(1, "not at all"; 7, "completely").

Marketing

Research and Development

Operations

Strategic Planning

Please indicate the duration of integration (1, "less than 6 months"; 4, "14 to 17 months"; 7, "more than 24 months").

Human Integration (Organizational Structure, Culture, and HR)

Please indicate the duration of integration (1, "less than 6 months; 4, "14 to 17 months"; 7, "more than 24 months").

Marketing

Research and Development

Operations

Strategic Planning

Employees of the target firm

...were critical about the change

...were critical about the acquirer managers

Alpha

Loading

$0.932 / 0.893$

0.82

0.937

0.918

0.859

..supported union activities against the change

...supported actions of colleagues against the change

...complained about the change to superiors

Who was responsible for the execution and coordination of the M\&A process?

Who was responsible for the execution and coordination of the M\&A process?

Please indicate the annual sales after the acquisition

Please indicate the average firm growth in three years prior to the acquisition

Please indicate the average firm growth following the acquisition

Decisions were made decentral
0.908
$0.922 / 0.890$

$0.958 / 0.945$

n.a.

n.a.

n.a.

n.a

n.a.

n.a.

n.a. 
Relative Size

Acquisition Experience

Organizational Structure
Please compare the annual sales of the target with the acquirer in the last year prior the acquisition

How many acquisitions has your firm conducted in the last five years

The operating management philosophy of the top management is...

Tight formal control of most operations by means of sophisticated control and information systems VS. Loose, informal control, heavy dependence on

informal relations and norm of co-operation for getting work done

Strong emphasis on always getting personnel to follow the formally laid down procedures VS. Strong emphasis in getting things done even if this means disregarding formal procedures

Strong insistence on a uniform managerial style throughout the business unit

VS. Managers' operating styles allowed to range freely from the very formal to the very informal

Strong emphasis on getting line and staff personnel to adhere closely to formal job descriptions VS. Strong tendency to let the requirements of the situation and the individual's personality define proper on-job behaviour 
Appendix C: Cross-loadings

\begin{tabular}{|c|c|c|c|c|c|c|c|c|c|c|c|c|c|c|c|}
\hline & & 1 & 2 & 3 & 4 & 5 & 6 & 7 & 8 & 9 & 10 & 11 & 12 & 13 & 14 \\
\hline 1 & Annual Sales & 1 & 0.0334 & 0.0446 & 0.1820 & 0.2645 & 0.0347 & 0.2223 & 0.1414 & 0.2988 & 0.0697 & 0.2276 & -0.1286 & 0.0920 & 0.2246 \\
\hline 2 & Human Integration Speed & 0.0334 & 1 & 0.7016 & 0.0024 & -0.1056 & 0.0471 & -0.0481 & -0.0468 & -0.1469 & 0.1289 & -0.1333 & 0.0612 & 0.0639 & 0.1906 \\
\hline 3 & Functional Integration Speed 1 & 0.0144 & 0.6140 & 0.9216 & 0.1668 & -0.3490 & -0.0030 & -0.1723 & -0.0150 & -0.2816 & 0.1775 & -0.2242 & 0.2188 & -0.0577 & 0.0005 \\
\hline 3 & Functional Integration Speed 2 & 0.0371 & 0.6976 & 0.9114 & 0.1022 & -0.2086 & 0.0558 & -0.1473 & -0.0814 & -0.1706 & 0.1330 & -0.1383 & 0.1847 & 0.0709 & 0.1301 \\
\hline 3 & Functional Integration Speed 3 & 0.0400 & 0.5984 & 0.9505 & 0.1272 & -0.3071 & 0.0351 & -0.2296 & -0.0665 & -0.2273 & 0.1941 & -0.1386 & 0.2332 & -0.0409 & 0.0481 \\
\hline 3 & Functional Integration Speed 4 & 0.0777 & 0.7151 & 0.9244 & 0.1086 & -0.2668 & 0.0486 & -0.1987 & -0.0861 & -0.2075 & 0.1731 & -0.2138 & 0.1179 & -0.0795 & 0.1045 \\
\hline 4 & Experience & 0.1820 & 0.0024 & 0.1388 & 1 & -0.0934 & -0.0273 & 0.1530 & 0.1066 & -0.0525 & -0.0435 & 0.0662 & 0.1020 & -0.0277 & 0.0973 \\
\hline 5 & Functional Integration 1 & 0.1808 & -0.1261 & -0.3173 & -0.0911 & 0.8725 & 0.3032 & 0.1493 & 0.1901 & 0.7094 & 0.0996 & 0.1236 & -0.0588 & 0.1683 & 0.3477 \\
\hline 5 & Functional Integration 2 & 0.2847 & 0.0613 & -0.1672 & -0.0400 & 0.7798 & 0.2055 & -0.0164 & 0.0485 & 0.5670 & 0.2763 & 0.0601 & -0.1123 & 0.1761 & 0.2262 \\
\hline 5 & Functional Integration 3 & 0.2508 & -0.1495 & -0.2945 & -0.0593 & 0.9130 & 0.1993 & 0.1335 & 0.1516 & 0.7151 & 0.1532 & 0.1103 & -0.0152 & 0.2267 & 0.2667 \\
\hline 5 & Functional Integration 4 & 0.2401 & -0.0745 & -0.2534 & -0.1189 & 0.8874 & 0.2015 & 0.0729 & 0.1379 & 0.7220 & 0.1143 & 0.0774 & -0.1282 & 0.2190 & 0.2304 \\
\hline 6 & Decentralized Decisions & 0.0347 & 0.0471 & 0.0343 & -0.0273 & 0.2663 & 1 & 0.0654 & 0.0917 & 0.2746 & 0.2368 & 0.1411 & 0.1181 & 0.1880 & 0.0951 \\
\hline 7 & Growth Post & 0.2223 & -0.0481 & -0.2039 & 0.1530 & 0.1156 & 0.0654 & 1 & 0.3874 & 0.1462 & -0.0567 & 0.3014 & -0.0388 & 0.2074 & 0.1217 \\
\hline 8 & Growth Prior & 0.1414 & -0.0468 & -0.0644 & 0.1066 & 0.1658 & 0.0917 & 0.3874 & 1 & 0.1205 & 0.0367 & 0.0811 & -0.0395 & 0.0731 & 0.1134 \\
\hline 9 & Human Integration 1 & 0.3173 & -0.1638 & -0.2501 & -0.0453 & 0.7696 & 0.2782 & 0.1151 & 0.1527 & 0.9373 & 0.1539 & 0.0719 & -0.1815 & 0.1432 & 0.3354 \\
\hline 9 & Human Integration 2 & 0.2618 & -0.1622 & -0.2462 & -0.0477 & 0.7318 & 0.1980 & 0.1306 & 0.0825 & 0.9176 & 0.0870 & 0.0616 & -0.1462 & 0.1933 & 0.3332 \\
\hline 9 & Human Integration 3 & 0.2128 & -0.0378 & -0.1367 & -0.0523 & 0.6303 & 0.2866 & 0.1686 & 0.0806 & 0.8594 & 0.0278 & 0.1032 & -0.1662 & 0.1499 & 0.4006 \\
\hline 10 & Structure 1 & 0.0699 & 0.1953 & 0.2755 & -0.0501 & 0.0951 & 0.1983 & -0.1243 & -0.0424 & 0.0735 & 0.9143 & -0.1283 & 0.2522 & -0.0156 & 0.0144 \\
\hline 10 & Structure 2 & 0.0727 & 0.1050 & 0.1524 & -0.0348 & 0.1256 & 0.2077 & -0.0092 & 0.0273 & 0.0639 & 0.9248 & -0.0710 & 0.3266 & -0.0041 & 0.0021 \\
\hline 10 & Structure 3 & 0.0310 & -0.0615 & -0.0328 & -0.1158 & 0.2953 & 0.2552 & -0.0320 & 0.1424 & 0.2129 & 0.7049 & -0.1187 & 0.1649 & -0.0851 & 0.1202 \\
\hline 10 & Structure 4 & 0.0337 & 0.0366 & 0.0321 & 0.0218 & 0.2212 & 0.2073 & 0.0250 & 0.1536 & 0.1540 & 0.7960 & -0.0392 & 0.1896 & -0.0552 & 0.1496 \\
\hline 11 & Relative Size & 0.2276 & -0.1333 & -0.1950 & 0.0662 & 0.1128 & 0.1411 & 0.3014 & 0.0811 & 0.0827 & -0.1045 & 1 & -0.0343 & 0.1341 & -0.0022 \\
\hline 12 & Resistance 1 & -0.1144 & 0.0566 & 0.2116 & 0.1186 & -0.1006 & 0.0680 & -0.0175 & -0.0022 & -0.1993 & 0.2228 & -0.0491 & 0.9147 & -0.1457 & -0.0826 \\
\hline 12 & Resistance 2 & -0.1042 & 0.0538 & 0.1779 & 0.1277 & -0.1458 & 0.0769 & -0.0198 & -0.0251 & -0.2089 & 0.2179 & -0.0403 & 0.8986 & -0.2207 & -0.1620 \\
\hline 12 & Resistance 3 & -0.0965 & 0.0961 & 0.2406 & 0.0389 & -0.0091 & 0.1683 & -0.0638 & -0.0388 & -0.0826 & 0.3420 & -0.0529 & 0.8910 & -0.0764 & 0.0142 \\
\hline 12 & Resistance 4 & -0.1010 & 0.0453 & 0.1926 & 0.0602 & -0.0689 & 0.0874 & -0.0641 & -0.0580 & -0.1304 & 0.2950 & -0.0312 & 0.9159 & -0.1382 & -0.0730 \\
\hline 12 & Resistance 5 & -0.1641 & 0.0255 & 0.1128 & 0.1143 & -0.0491 & 0.1327 & -0.0124 & -0.0555 & -0.1951 & 0.2633 & 0.0170 & 0.9084 & -0.1219 & -0.1964 \\
\hline 13 & Responsibilities_1 & 0.0920 & 0.0639 & -0.0349 & -0.0277 & 0.2279 & 0.1880 & 0.2074 & 0.0731 & 0.1791 & -0.0279 & 0.1341 & -0.1548 & 1 & 0.2084 \\
\hline 14 & Responsibilities_2 & 0.2246 & 0.1906 & 0.0700 & 0.0973 & 0.3162 & 0.0951 & 0.1217 & 0.1134 & 0.3835 & 0.0484 & -0.0022 & -0.1110 & 0.2084 & 1 \\
\hline
\end{tabular}


Appendix D: Fornell-Larcker Criteria

\begin{tabular}{|c|c|c|c|c|c|c|c|c|c|c|c|c|c|c|c|}
\hline & & 1 & 2 & 3 & 4 & 5 & 6 & 7 & 8 & 9 & 10 & 11 & 12 & 13 & 14 \\
\hline 1 & $\begin{array}{l}\text { Human Integration Speed } \\
\text { Functional Integration }\end{array}$ & 1 & & & & & & & & & & & & & \\
\hline 2 & Speed & 0.7016 & 0.9271 & & & & & & & & & & & & \\
\hline 3 & Human Integration & -0.1469 & -0.2438 & 0.9053 & & & & & & & & & & & \\
\hline 4 & Middle Managers & 0.1906 & 0.0700 & 0.3835 & 1 & & & & & & & & & & \\
\hline 5 & Resistance & 0.0612 & 0.2061 & -0.1807 & -0.1110 & 0.9058 & & & & & & & & & \\
\hline 6 & Functional Integration & -0.1056 & -0.3116 & 0.7931 & 0.3162 & -0.0822 & 0.8646 & & & & & & & & \\
\hline 7 & Top Management & 0.0639 & -0.0349 & 0.1791 & 0.2084 & -0.1548 & 0.2279 & 1 & & & & & & & \\
\hline 8 & Annual Sales & 0.0334 & 0.0446 & 0.2988 & 0.2246 & -0.1286 & 0.2645 & 0.0920 & 1 & & & & & & \\
\hline 9 & Decentralized Decisions & 0.0471 & 0.0343 & 0.2746 & 0.0951 & 0.1181 & 0.2663 & 0.1880 & 0.0347 & 1 & & & & & \\
\hline 10 & Experience & 0.0024 & 0.1388 & -0.0525 & 0.0973 & 0.1020 & -0.0934 & -0.0277 & 0.1820 & -0.0273 & 1 & & & & \\
\hline 11 & Growth Post & -0.0481 & -0.2039 & 0.1462 & 0.1217 & -0.0388 & 0.1156 & 0.2074 & 0.2223 & 0.0654 & 0.1530 & 1 & & & \\
\hline 12 & Growth Prior & -0.0468 & -0.0644 & 0.1205 & 0.1134 & -0.0395 & 0.1658 & 0.0731 & 0.1414 & 0.0917 & 0.1066 & 0.3874 & 1 & & \\
\hline 13 & Relative Size & -0.1333 & -0.1950 & 0.0827 & -0.0022 & -0.0343 & 0.1128 & 0.1341 & 0.2276 & 0.1411 & 0.0662 & 0.3014 & 0.0811 & 1 & \\
\hline 14 & Structure & 0.1289 & 0.1853 & 0.1095 & 0.0484 & 0.2958 & 0.1652 & -0.0279 & 0.0697 & 0.2368 & -0.0435 & -0.0567 & 0.0367 & -0.1045 & 0.8399 \\
\hline
\end{tabular}

